\title{
Unhappy Memories
}

\author{
LORD GRANTLEY
}

From Silver Spoon, Being Extracts from the Random Reminiscences of Lord Grantley, ed. Mary and Alan Wood (London: Hutchinson, 1954) p. 209. Lord Grantley (Richard Henry Brinsley Norton, 6th Baron, 1892-1954) divided his career between international finance and films. As Managing Director of Pinewood Studios and Chairman of the British Film Producers Association, he was sometimes referred to as 'The Wicked Uncle' in the film world because of his monocle and sinister expression. He had a reputation as a witty raconteur. His connection with Shaw began when Gabriel Pascal approached him about the making of the film version of Pygmalion.

I can remember a number of meetings with him in his awful little house at Ayot St Lawrence, which I came to know so well. It was thoroughly suburban, in some ghastly Edwardian style with little bay windows, and had the most tasteless furnishings; the general impression being of a boarding house sprinkled with the souvenirs of a great man. There were doyleys under the cakes, thin bread and butter in rolls for tea, and all that sort of thing. It was only redeemed by the books and by Shaw himself.

Ayot St Lawrence had a special purgatory for me in never being allowed to smoke. Once, when I could not bear it any longer, I excused myself, left Gaby and Shaw talking inside, and went out to light a cigarette. I had a walk and a smoke, and the next thing I knew was that Shaw came charging out of the house, and started abusing me because I had thrown the cigarette end away on one of the flower beds. He was so vehement that his accent grew more and more Irish.

'I thought you told me you were a gardener,' he said.

'Well, so I am ....'

'And look at you polluting me beautiful flowers!' (referring to one or two tattered antirrhinums).

It is hard to know what to do with a rude old man who is very old indeed, and very great. So far as I can remember, I just picked up the cigarette end, and I suppose put it in my pocket. 